\title{
Urinary saturation and nephrocalcinosis in preterm infants: effect of parenteral nutrition
}

\author{
B Hoppe, A Hesse, T Neuhaus, S Fanconi, Ishilde Forster, N Blau, E Leumann
}

\begin{abstract}
Urinary lithogenic and inhibitory factors were studied in 27 preterm infants; 16 had total parenteral nutrition (TPN) and 11 had breastmilk with an additional glucose-sodium chloride infusion. Urines were collected for 24 hours on day 2 (period A), day $3(B)$, and once between days 4 and 10 (C). Urinary calcium oxalate saturation was calculated by the computer program EQUIL 2. Renal ultrasonography was performed every second week until discharge.
\end{abstract}

The calcium/creatinine ratio increased in infants on TPN (A $0.91 ; C 1.68 \mathrm{~mol} / \mathrm{mol})$ and was significantly higher at period $C$ than that in infants on breastmilk/infusion (A 0.52; C 0.36). The oxalate/creatinine ratio was persistently higher with TPN (203 $\mathrm{mmol} / \mathrm{mol}$ ) than with breastmills infusion $(98 ; 137)$. The citrate/creatinine remained constant with TPN $(0.44$ $\mathrm{mol} / \mathrm{mol}$ ), whereas it increased significantly with breastmill/infusion (0.26; 0.49). Calcium/citrate rose considerably with TPN, but decreased with breastmilk/infusion to a significantly lower level than with TPN. The urinary calcium oxalate saturation increased with TPN $(2 \cdot 4 ; 4.5)$ and decreased with breastmilkJ infusion $(2 \cdot 1 ; 1 \cdot 5)$ to a significantly lower value than with TPN. Nephrocalcinosis developed in two infants on TPN. Mean daily calcium intake was similar in both groups, whereas protein, sodium, and phosphorus intake were significantly higher on TPN.

It is concluded that the increase in urinary calcium oxalate saturation observed with TPN is due to the combined effect of an increased urinary calcium excretion and higher urinary oxalate/ creatinine and calcium/citrate ratios. The changes observed are likely to be caused by TPN itself, which differs in several respects from breastmilk feeding.

(Arch Dis Child 1993; 69: 299-303)

Nephrocalcinosis is a well known complication in critically ill preterm infants ${ }^{1-6}$ and its aetiology is still a matter of debate. Hypercalciuria induced by frusemide administration was at first considered to be the main cause of nephrocalcinosis. ${ }^{1-3}$ Indeed 20 to $64 \%$ of all premature infants receiving frusemide develop nephrocalcinosis. ${ }^{4-6}$ Long term dexamethasone treatment in bronchopulmonary dysplasia has also been incriminated to cause renal calcinosis by raising urinary calcium excretion. ${ }^{7}$ However, a correlation was noted only between the duration of ventilation or oxygen requirement and the development of nephrocalcinosis by Short and Cooke. ${ }^{8}$ Finally Campfield and Braden found a rising urinary oxalate excretion in very low birthweight (VLBW) infants receiving total parenteral nutrition (TPN) and hence suggested that the risk of calcium oxalate precipitation and nephrocalcinosis was increased. ${ }^{9} 10$

In order to understand better the underlying mechanisms and the effect, if any, of TPN on the risk of renal calcification, we studied urinary lithogenic and inhibitory substances (for example citrate) and the urinary calcium oxalate saturation in preterm infants receiving either TPN or breastmilk with an additional glucose-sodium chloride infusion. In addition, renal ultrasound examinations were performed repeatedly.

\section{Patients and methods}

Preterm infants $<35$ weeks' gestation were studied. We excluded infants who were small for date and those with renal or intestinal disease, complex malformations, or cardiac anomalies. Thirty five infants entered the study; eight patients (six on TPN and two on breastmilk/infusion) were excluded because of an incomplete urine collection. Of the remaining 27 infants 16 had TPN and 11 received breastmilk/infusion. The decision about the form of nutrition was based on clinical grounds as randomisation was not acceptable for ethical reasons. Accordingly, infants on TPN were more critically ill and had a lower mean birth weight (table 1). For infants on TPN, Vamin glucose $7 \%$ containing $50 \mathrm{mmol} / 1$ sodium chloride, $20 \mathrm{mmol} / 1$ potassium, $2.5 \mathrm{mmol} / 1$ calcium, and $1.5 \mathrm{mmol} / \mathrm{l}$ magnesium and Intralipid 20\% (Kabi Pharmacia, Stockholm, Sweden) were used with added vitamins and trace elements. TPN was started on the second day of life with one third of the final amount. The complete intake consisted of $35 \mathrm{ml}$ amino acid solution, $10 \mathrm{ml}$ fat emulsion, $60 \mathrm{ml}$ glucose $10 \%$, and $20 \mathrm{ml}$ glucose $50 \%$ (expressed per $\mathrm{kg}$ and day) and was usually reached by the seventh day. Infants receiving breastmilk had an additional glucose-sodiumchloride infusion. No infant received dexamethasone or high doses $(>1.5 \mathrm{mg} / \mathrm{kg} /$ day $)$ of frusemide. The acid-base status was determined daily and was corrected as needed to keep the base excess to $\pm 3 \mathrm{mmol} / 1$.

Urines were collected in plastic bags for 24 hours on day 2 (period A), day 3 (B), and once 
Table 1 Clinical data of infants studied; values are mean (SD)

\begin{tabular}{|c|c|c|c|c|c|}
\hline & \multicolumn{3}{|l|}{$T P N(n=16)$} & \multicolumn{2}{|c|}{ Breastmilk/infusion $(n=11)$} \\
\hline $\begin{array}{l}\text { No of infants ventilated } \\
\text { Birth weight }(\mathrm{g}) \\
\text { Gestational age (weeks) } \\
\text { Vitamin } D_{3} \text { (IU/day) }\end{array}$ & $\begin{array}{r}14 \\
1526 \\
30 \\
350\end{array}$ & & $\star$ & $\begin{array}{r}10 \\
2085 \\
33 \cdot 1 \\
700 \mathrm{~b}\end{array}$ & outh \\
\hline $\begin{array}{l}\text { Frusemide dose }(\mathrm{mg} / \mathrm{kg} / \text { day }) \\
\text { Ascorbic acid (mg/day) } \\
\text { Total urine volume (ml/24 hours) }\end{array}$ & $\begin{array}{l}\text { Period } A \\
0 \cdot 44(0 \cdot 49) \\
16 \cdot 5(10 \cdot 8) \\
97(54)\end{array}$ & $\begin{array}{l}\text { Period } C \\
0.55(0.49) \\
16 \cdot 5(10 \cdot 8) \\
105(55)\end{array}$ & $\star \star$ & $\begin{array}{l}\text { Period } A \\
0 \cdot 43(0 \cdot 62) \\
2 \cdot 8(1 \cdot 2) \\
121(74)\end{array}$ & $\begin{array}{l}\text { Period } C \\
0.40(0.40) \\
10 \cdot 6(5 \cdot 6) \\
104(55)\end{array}$ \\
\hline
\end{tabular}

Table 2 Urinary calcium: total excretion, concentration, and $\mathrm{Ca} / \mathrm{Cr}$ ratio; values are mean (SEM)

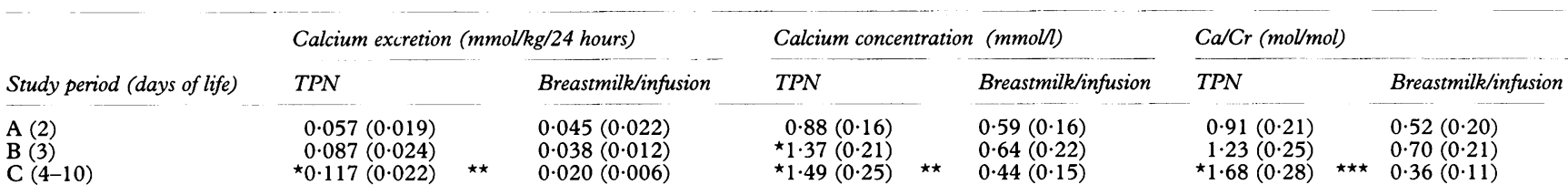

${ }^{\star} \mathrm{p}<0.05$ (TPN: B and/or C $v \mathrm{~A} ;{ }^{\star \star} \mathrm{p}<0.005$ (breastmilk/infusion $v \mathrm{TPN}$ ); ${ }^{\star \star \star}{ }^{\star} \mathrm{p}<0.001$ (breastmilk/infusion $v$ TPN).

Table 3 Urinary oxalate excretion, Ox/Cr ratio and calcium oxalate saturation; values are mean (SEM)

\begin{tabular}{|c|c|c|c|c|c|c|c|c|}
\hline \multirow[b]{2}{*}{ Study period (days of life) } & \multicolumn{2}{|c|}{ Oxalate excretion ( $\mu \mathrm{mol} / \mathrm{kg} / 24$ hours) } & \multicolumn{3}{|c|}{$\mathrm{Ox} / \mathrm{Cr}(\mathrm{mmol} / \mathrm{mol})$} & \multicolumn{3}{|c|}{ Calcium oxalate saturation } \\
\hline & $T P N$ & Breastmilk/infusion & $T P N$ & & Breastmilk/infusion & $T P N$ & & Breastmilk/infusion \\
\hline $\begin{array}{l}\text { A (2) } \\
\text { B (3) } \\
\text { C (4-10) }\end{array}$ & $\begin{array}{l}10.0(2.0) \\
11.8(1.6) \\
11.4(1.8)\end{array}$ & $\begin{array}{l}7 \cdot 5(1 \cdot 1) \\
7 \cdot 6(0.96) \\
8 \cdot 4(1 \cdot 6)\end{array}$ & $\begin{array}{l}202(41) \\
199(32) \\
203(25)\end{array}$ & $t$ & $\begin{array}{c}98(5) \\
119(15) \\
137(22)\end{array}$ & $\begin{array}{r}2.41(0.48) \\
\star 4.05(0.88) \\
\star 4.47(0.89)\end{array}$ & $t$ & $\begin{array}{l}2.12(0.60) \\
1.68(0.36) \\
1.52(0.36)\end{array}$ \\
\hline
\end{tabular}

${ }^{\star} \mathrm{p}<0.05$ (TPN: B and C $\left.v \mathrm{~A}\right) ;+\mathrm{p}<0.05$ (breastmilk/infusion $v$ TPN).

between days 4 and 10 (C) after full nutrition was reached, which was the case on day 7 $( \pm 1 \cdot 8)$ in infants on TPN and day $6( \pm 1 \cdot 3)$ in those on breastmilk/infusion. The bags were emptied at two hour intervals into bottles containing $6 \mathrm{M}$ hydrochloric acid to acidify the urine to $\mathrm{pH}<2$. Urines were frozen at the end of the collection and analysed within one month. Separation and quantification of oxalate was performed using a Dionex Series $4000 \mathrm{i}$ gradient ion chromatography system (Dionex Co, Sunnyvale, CA, USA). The background conductivity was minimised with 25 $\mathrm{mM}$ sulphuric acid regenerant. ${ }^{11}$ Citrate was determined using the citrate lyase method. ${ }^{12}$ The following analyses were done on a Technicon RA-1000 Analyzer (Technicon Instrumental Corporation, Tarrytown, NY, USA): creatinine by a standard kinetic Jaffé procedure, sodium and potassium by ion selective electrodes, calcium with a colorimetric cresolphthalein-complexon method, magnesium with a xylidyl blue reaction, and inorganic phophorus using an ultraviolet molybdate complex method. The $\mathrm{pH}$ of the urine was determined by indicator sticks (Boehringer Mannheim, Germany) in freshly voided morning specimens after 24 hour $\mathrm{pH}$ profiles had shown small fluctuations only $( \pm 0 \cdot 5)$. From these parameters and from the urinary volume per 24 hours the urinary calcium oxalate saturation was calculated by the computer program EQUIL 2 according to Werness et al. ${ }^{13}$ Renal ultrasonography was performed every second week until discharge using a real time sector scanner with a $7 \cdot 5$ or $5 \mathrm{MHz}$ transducer (Sonolayer, V-SSA 100 A, Toshiba Medical Services, Zurich, Switzerland).
Data were expressed as mean (SEM). Significance was calculated using the Wilcoxon signed rank test or the Wilcoxon rank sum test, respectively; $p$ values less than 0.05 were considered significant.

The study was approved by the ethical committee of the children's hospital.

\section{Results}

The relevant clinical data of the 27 preterm infants are summarised in table 1 . No significant differences between the two groups were observed except for the mean birth weight, which was significantly $(p<0.05)$ lower in the infants on TPN. Relative weight loss was similar in both groups reaching $-4.5 \%$ (average) at period C.

The urinary calcium/creatinine ratio $(\mathrm{Ca} / \mathrm{Cr}$, $\mathrm{mol} / \mathrm{mol})$ increased significantly $(\mathrm{p}<0.05)$ in those on TPN from 0.91 in period $A$ to 1.68 in period $C$ (table 2; figure). The total urinary calcium concentration and excretion increased similarly. In contrast calcium excretion did not rise in infants on breastmilk/infusion. As a result their $\mathrm{Ca} / \mathrm{Cr}$ ratio in period $\mathrm{C}$ was significantly $(\mathrm{p}<0.001)$ lower $(0.36)$ than in those on TPN (figure), as were the urinary calcium concentration and excretion $(p<0.005$; table 2$)$.

The oxalate/creatinine $(\mathrm{Ox} / \mathrm{Cr}, \mathrm{mmol} / \mathrm{mol})$ ratio in infants receiving TPN remained constant but was consistently higher (A 202; C203) than that in those on breastmilk/ infusion (98; 137, table 3 and figure). This difference was significant $(p<0.05)$ at period $B$ only. Urinary oxalate excretion ( $\mu \mathrm{mol} / \mathrm{kg} / 24$ hours) increased slightly in both groups, being persistently higher in TPN than in breastmilk/infusion. 

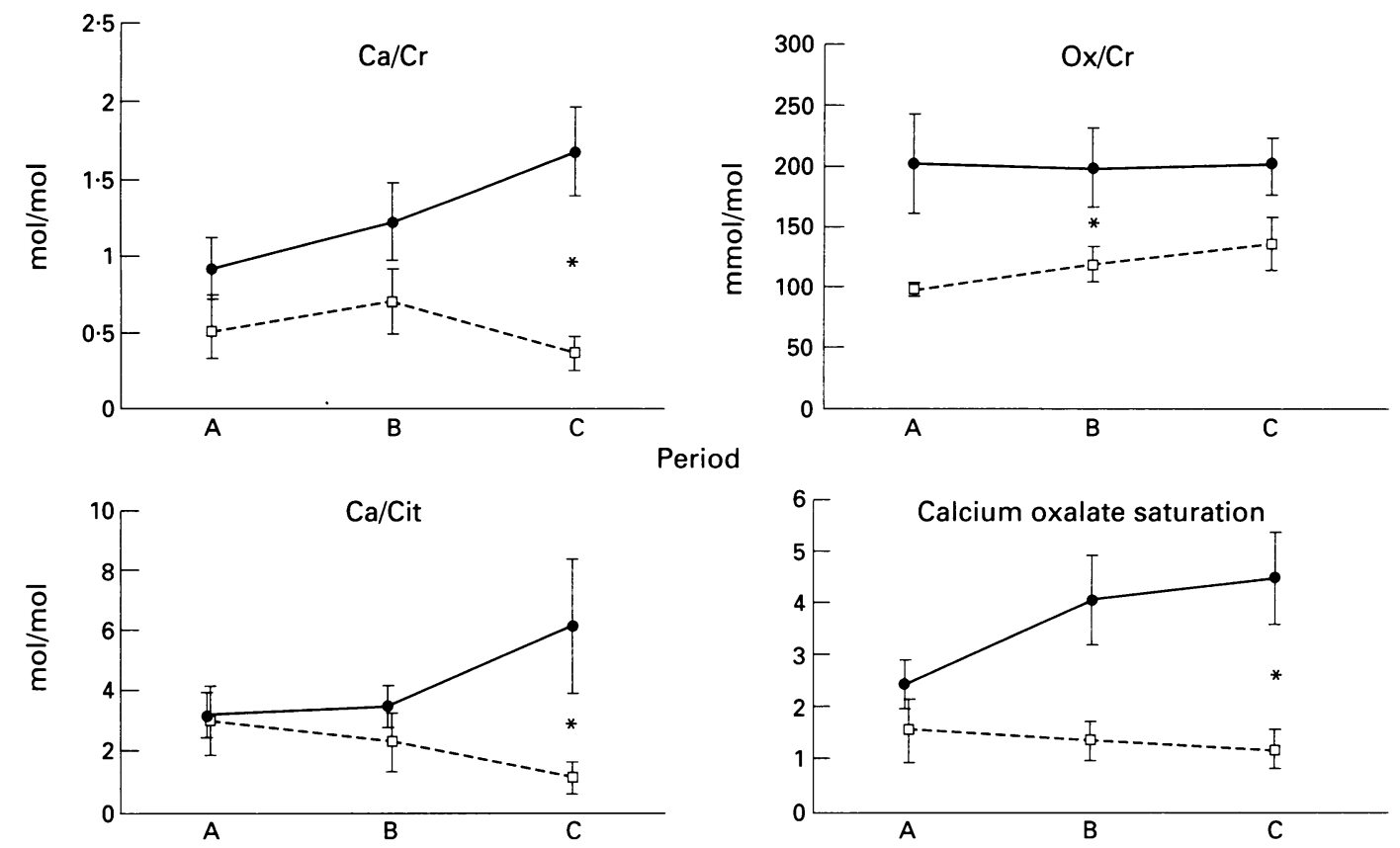

Period

$$
\begin{aligned}
& \longrightarrow \text { TPN } \\
& -0-\text { Breastmilk/infusion }
\end{aligned}
$$

Mean (SEM) $\mathrm{Ca} / \mathrm{Cr}, \mathrm{Ox} / \mathrm{Cr}$, and $\mathrm{Ca} /$ Cit ratios and calcium oxalate saturation in 24 hour urines of preterm infants receiving either TPN or breastmilk/infusion at periods $A, B$, and $C$; *significant difference between TPN and breastmilk/infusion.

The mean urinary citrate (Cit) excretion (table 4) increased in both groups to a comparable level at period C $(0.035 \mathrm{mmol} / \mathrm{kg} /$ day in TPN, 0.031 in breastmilk/infusion). In those on breastmilk/infusion the $\mathrm{Cit} / \mathrm{Cr}$ ratio was initially (A) considerably lower, but increased significantly $(\mathrm{p}<0.01)$ to a slightly higher level (C) than in those on TPN. An important difference was observed in the $\mathrm{Ca} / \mathrm{Cit}$ ratio, which increased twofold in infants on TPN, yet steadily decreased in those on breastmilk/infusion to a significantly $(\mathrm{p}<0.005)$ lower value at period C (table 4; figure), than in TPN.

The urinary calcium oxalate saturation (table 3, figure) was similar in both groups at period A $(2 \cdot 41$ in TPN; $2 \cdot 12$ in breastmilk infusion). A significant $(\mathrm{p}<0.05)$ increase was then observed in TPN to 4.47 in period C. In contrast a steady decrease was noted in infants on breastmilk/infusion (table 3 ), the calcium oxalate saturation being significantly $(p<0.05)$ lower than in TPN at period C $(1 \cdot 52)$.

Slight medullary nephrocalcinosis was diagnosed ultrasonographically on days 31 and 18, respectively, in two infants on TPN. Nephrocalcinosis remained unchanged at the time of transfer to other hospitals on days 45 and 60 . Ionised serum calcium was comparable at period A $(0.99 \mathrm{mmol} / 1$ in TPN; 0.98 $\mathrm{mmol} / \mathrm{l}$ in breastmilk/infusion), but slightly higher at period C in TPN $(1.12$ in TPN $v$ 1.02 in breastmilk/infusion). Serum sodium

Table 4 Urinary citrate excretion, Cit/Cr and Ca/Cit ratios; values are mean (SEM)

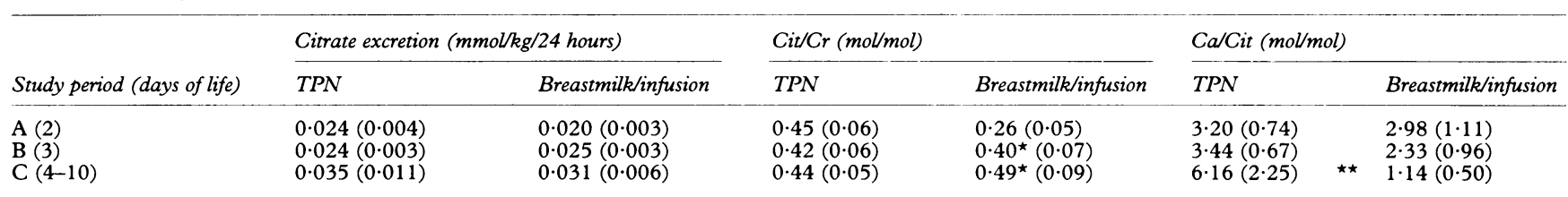

${ }^{\star} \mathrm{p}<0.05$ (breastmilk/infusion: B and C $v \mathrm{~A}$ ); ${ }^{\star \star} \mathrm{p}<0.005$ (breastmilk/infusion $v \mathrm{TPN}$ ).

\begin{tabular}{|c|c|c|c|c|c|c|c|c|c|c|c|c|}
\hline \multirow[b]{2}{*}{$\begin{array}{l}\text { Study period } \\
\text { (days of life) }\end{array}$} & \multicolumn{3}{|c|}{ Protein (g/kg/24 hours) } & \multicolumn{3}{|c|}{ Sodium (mmol/kg/24 hours) } & \multicolumn{3}{|c|}{ Phosphorus (mmol/kg/24 hours) } & \multicolumn{3}{|c|}{ Calcium ( $\mathrm{mmol} / \mathrm{kg} / 24$ hours) } \\
\hline & $T P N$ & & $\begin{array}{l}\text { Breastmilk/ } \\
\text { infusion }\end{array}$ & $T P N$ & & $\begin{array}{l}\text { Breastmilk/ } \\
\text { infusion }\end{array}$ & $T P N$ & & $\begin{array}{l}\text { Breastmilk/ } \\
\text { infusion }\end{array}$ & $T P N$ & & $\begin{array}{l}\text { Breastmilk/ } \\
\text { infusion }\end{array}$ \\
\hline $\begin{array}{l}\text { A (2) } \\
\text { B (3) } \\
C(4-10)\end{array}$ & $\begin{array}{l}1.33(0 \cdot 17) \\
1.81(0 \cdot 20) \\
2 \cdot 48(0.17)\end{array}$ & $\begin{array}{l}\star \star \\
\star \star \\
\star \star\end{array}$ & $\begin{array}{l}0.32(0.04) \\
0.65(0.09) \\
1.33(0.22)\end{array}$ & $\begin{array}{l}0.94(0.12) \\
1 \cdot 28(0 \cdot 14) \\
1.74(0.11)\end{array}$ & $\stackrel{\star}{\star}$ & $\begin{array}{l}0.61(0.05) \\
0.71(0.05) \\
0.96(0.09)\end{array}$ & $\begin{array}{l}0.85(0.06) \\
0.78(0.06) \\
0.83(0.06)\end{array}$ & $\begin{array}{l}\star \star \\
\star \star \\
\star\end{array}$ & $\begin{array}{l}0.14(0.02) \\
0.29(0.05) \\
0.55(0.09)\end{array}$ & $\begin{array}{l}0.72(0.11) \\
0.84(0.06) \\
0.92(0.07)\end{array}$ & & $\begin{array}{l}0.43(0.39) \\
0.63(0 \cdot 11) \\
1.00(0 \cdot 16)\end{array}$ \\
\hline
\end{tabular}

Table 5 Dietary intake: preterm infants receiving TPN or breastmilk/infusion; values are mean (SEM)

${ }^{\star} \mathrm{p}<0.05$ (breastmilk/infusion $v \mathrm{TPN}$ ); ${ }^{\star \star} \mathrm{p}<0.001$ (breastmilk/infusion $v \mathrm{TPN}$ ). 
and creatinine concentrations did not differ between the two study groups.

The amount of protein, sodium, and phosphorus administered per day (per kg body weight) increased in both groups, but remained significantly $(p<0.05)$ lower for those on breastmilk/infusion during the whole study period (table 5). In contrast, calcium intake was similar in both groups at periods $B$ and $C$. The ascorbic acid dosage given (per $\mathrm{kg}$ and day) was lower in those on breastmilk/infusion, particularly at period $A(p<0.0001 ;$ table 1$)$.

\section{Discussion}

A steady increase of the urinary calcium oxalate saturation in infants receiving TPN was the main finding. It is the result of several factors, that is a rising urinary calcium excretion, an $\mathrm{Ox} / \mathrm{Cr}$ ratio remaining constantly higher than that in infants on breastmilk/ infusion, and an increasing $\mathrm{Ca} / \mathrm{Cit}$ ratio. In contrast, the calcium oxalate saturation in infants on breastmilk/infusion decreased further because of lower ratios for $\mathrm{Ca} / \mathrm{Cr}$, $\mathrm{Ox} / \mathrm{Cr}$, and $\mathrm{Ca} / \mathrm{Cit}$. These results clearly show that the infants on TPN were at increased risk of calcium oxalate precipitation. This is further substantiated by the finding of medullary nephrocalcinosis in two infants on TPN.

Could this difference be due to the lower mean birth weight of the infants on TPN as compared with those on breastmilk/infusion? This appears unlikely as the excretion rates, if expressed per kg body weight, showed the same tendency. Furthermore, the initial $\mathrm{Ca} / \mathrm{Cr}, \mathrm{Ox} / \mathrm{Cr}$, and $\mathrm{Ca} / \mathrm{Cit}$ ratios, as well as the urinary calcium oxalate saturation were similar in both groups at period A. However, an effect of different renal maturation between the two groups is not formally excluded. ${ }^{14}$

It is noteworthy that both groups had the same frusemide dosage and a comparable daily calcium intake, yet only infants on TPN showed an increase of the urinary calcium excretion and of the $\mathrm{Ca} / \mathrm{Cr}$ ratio. Thus we cannot incriminate frusemide for the rising urinary calcium, as was done in other studies where higher dosages of frusemide were administered. ${ }^{1-6}$

Contrary to our expectations and to the results of Campfield and Braden, 910 no significant increase of the urinary oxalate excretion was found. However, the $\mathrm{Ox} / \mathrm{Cr}$ ratio in those on TPN was persistently higher than that in those on breastmilk/infusion. Campfield and Braden observed a rise of the oxalate excretion and of the $\mathrm{Ox} / \mathrm{Cr}$ ratio in VLBW infants on TPN after the protein intake was increased from 0.5 to $1.5 \mathrm{~g} / \mathrm{kg} /$ day. ${ }^{9}$ These authors used a standard amino acid solution (Travasol, Travenol Laboratories) and a paediatric amino acid solution (Trophamine, Kendall McGraw Lab). The difference between their data and our results is thus not explained by the protein content of TPN per se, as the mean protein supply in our study was consistently higher. However, it might be related to differences in the amino acid composition in TPN or to another dosage of supplements. The amount of ascorbic acid (a precursor of oxalate) administered by Campfield and Braden ${ }^{9}$ was considerably higher ( $35 \mathrm{mg} /$ day) than in our study $(16.5 \mathrm{mg} /$ day $)$. The studies are not entirely comparable for other reasons, for example urine specimens were collected during eight hour periods and oxalate was analysed by oxalate oxidase. ${ }^{9}$ Nevertheless, the role of the urinary oxalate excretion cannot easily be dismissed. Oxalate is $10-15$ times more potent than an equimolar amount of calcium in increasing the risk of calcium oxalate precipitation. ${ }^{15}$ Hence, the higher $\mathrm{Ox} / \mathrm{Cr}$ ratio found in TPN also contributed to the increase in urinary calcium oxalate saturation.

Hardly any data exist about urinary citrate excretion in preterm infants. ${ }^{1617}$ Citrate is a potent inhibitor of calcium oxalate aggregation. ${ }^{1819}$ We found a similar increase of the citrate excretion in both groups. However, the $\mathrm{Cit} / \mathrm{Cr}$ ratio increased only in the infants receiving breastmilk/infusion and remained stable in those on TPN. Due to the rise of the urinary calcium excretion, there was a twofold increase of the $\mathrm{Ca} / \mathrm{Cit}$ ratio in TPN as opposed to a decrease in those on breastmilk/infusion. The higher the $\mathrm{Ca} / \mathrm{Cit}$ ratio, the greater is the risk of nephrocalcinosis and nephrolithiasis. ${ }^{20}$ These changes, together with the higher urinary oxalate excretion, contributed primarily to the increasing calcium oxalate saturation in infants on TPN. These infants clearly are at risk for renal calcifications. As a corollary, two of the infants on TPN, but none of those on breastmilk/infusion, developed nephrocalcinosis as demonstrated by ultrasonography.

Could these results be explained by differences in nutrition? Indeed the mean daily intake (per $\mathrm{kg}$ of body weight) of protein, sodium, and phosphorus was significantly higher in those TPN than in those on breastmilk/infusion. The higher protein content and a different amino acid composition of the parenteral solution used as compared with breastmilk may have resulted in a higher urinary oxalate excretion. ${ }^{9}$ The infants on TPN also had a higher dosage of ascorbic acid, a (potential) precursor of oxalate. ${ }^{15}$ Furthermore, the higher sodium intake may have increased calcium excretion as renal sodium and calcium handling are closely linked. ${ }^{21}$ Additional studies in preterm infants are needed to evaluate the influence of nutritional factors on urinary lithogenic and inhibitory parameters and on the risk of nephrocalcinosis.

In conclusion, we observed a considerably higher risk of calcium oxalate precipitation and of nephrocalcinosis in preterm infants on TPN than in those on breastmilk/infusion. The higher calcium oxalate saturation was due to increased calcium excretion, higher $\mathrm{Ca} / \mathrm{Cit}$ ratios, and persistently higher $\mathrm{Ox} / \mathrm{Cr}$ ratios. Both groups studied had similar (low) doses of frusemide, but the infants on TPN had a considerably higher daily intake of protein, sodium, phosphorus, and ascorbic acid.

We thank Sibylle Leikauf, Zurich, Dagmar Lange, and Carmen Wischnat, Bonn, for laboratory assistance and especially the nurses of the neonatal intensive care unit, University Children's nurses of the neonatal intensive care unit, Universich
Hospital, Zurich for their outstanding support. 
This work was supported by the Deutsche Forschungsgemeinschaft, Grant No 1272/1-1, and the Schweizer Nationalfonds, Grant No 32-26286.89.

1 Hufnagle KG, Khan SN, Penn D, Cacciarelli A, Williams P. Renal calcifications: a complication of long term furosemide therapy in preterm infants. Pediatrics 1982; 70: 360-3.

2 Kenney IJ, Aiken CG, Lenney W. Frusemide-induced nephrocalcinosis in very low birth weight infants. Pediatr Radiol 1988; 18: 323-5.

3 Woolfield N, Haslam R, Le Quesne G, Chambers HM, Hogg R, Jureidini K. Ultrasound diagnosis of nephrocalcinosis in preterm infants. Arch Dis Child 1988; 63: 86-8.

4 Gilsanz V, Fernal W, Reid BS, Stanley P, Ramos A Nephrocalcinosis in preterm infants. Radiology 1985; 154: Nephrocalcinosis in preterm infants. Radiology 1985; 154

5 Ezzedeen F, Adelmann RD, Ahlfors CE. Renal calcification in preterm infants: pathophysiology and long term sequelae. $\mathcal{F}$ Pediatr 1988; 113: 532-9.

6 Jacinto JS, Modanlou HD, Crade MC, Strauss AA, Bosu $S K$. Renal calcification incidence in very low birth weight infants. Pediatrics 1988; 81: 31-5.

7 Kamitsuka MD, Peloquin D. Renal calcification after dexamethasone in infants with bronchopulmonary dysplasia. Lancet 1991; 337: 626 .

8 Short A, Cooke RWI. The incidence of renal calcification in preterm infants. Arch Dis Child 1991; 66: 412-7.

9 Campfield TJ, Braden GL. Urinary oxalate excretion by very low birth weight infants receiving parenteral nutrivery low birth weight infants recei
tion. Pediatrics $1989 ; 84: 860-3$.

10 Campfield TJ, Braden GL. Effect of parenteral nutrition on urinary calcium oxalate saturation. Pediatr Res 1991; 29: 339A (abst).
11 Classen A, Hesse A. Measurement of urinary oxalate: an enzymatic and ion chromatographic method compared. 7 Clin Chem Clin Biochem 1987; 25: 95-9.

12 Möllering $\mathrm{H}$, Gruber W. Determination of citrate with citrate lyase. Anal Biochem 1966; 17: 369-75.

13 Werness PG, Brown CM, Smith LH, Finlayson B. Equil 2: a basic computer program for the calculation of urinary

14 Vanpeé $M$, Herin P, Zetterstrom R, Aperia A. Postnatal development of renal function in very low birthweight infants. Acta Paediatr Scand 1988; 77: 191-7.

15 Robertson WG, Peacock M, Heyburn PJ, Marshall DH, Clark PB. Risk factors in calcium stone disease of the urinary tract. $B r \mathcal{F}$ Urol $1978 ; 50: 449-54$.

16 Schärer K, Manz F. Renal handling of citrate in children with various kidney disorders. International fournal of Pediatric Nephrology 1985; 6: 79-88.

17 Murphy JL, Mendoza SA. Decreased urinary citrate in premature infants with lung disease. Child Nephrol Urol 1990; mature infant

18 Hesse A, Hoppe B, Classen A, Vahlensieck W. Treatment of calcium-oxalate urolithiasis with alkali citrate: effects on urinary parameters in patients on standardized and free diets. In: Walker VR, Sutton RAL, Cameron ECB, Pak CYC, Robertson WG, eds. Urolithiasis. New York: Plenum Press, 1989: 813-5.

19 Pak CYC, Fuller C, Sakhaee K, Preminger GM, Britton F. Long-term treatment of calcium nephrolithiasis with potassium citrate. $\mathcal{F}$ Urol 1985 ; 134: 11-9.

20 Parks JH, Coe FL. A urinary calcium-citrate index for the evaluation of nephrolithiasis. Kidney Int 1986; 30: 85-90.

21 Muldowney FP, Freaney R, Moloney MF. Importance of dietary sodium in the hypercalciuria syndrome. Kidney Int 1982; 22: 292-6. 